\title{
Lattice-work corridors for climate change: a conceptual framework for biodiversity conservation and social-ecological resilience in a tropical elevational gradient
}

\author{
$\underline{\text { Patricia A. Townsend }}^{1}$ and $\underline{\text { Karen L. Masters }}^{2}$
}

\begin{abstract}
Rapid climate change poses complex challenges for conservation, especially in tropical developing countries where biodiversity is high while financial and technical resources are limited. The complexity is heightened by uncertainty in predicted effects, both for ecological systems and human communities that depend heavily on natural resource extraction and use. Effective conservation plans and measures must be inexpensive, fast-acting, and able to increase the resilience of both the ecosystem and the social-ecological system. We present conservation practitioners with a framework that strategically integrates climate change planning into connectivity measures for tropical mountain ecosystems in Costa Rica. We propose a strategy for doubling the amount of habitat currently protected in riparian corridors using measures that are relatively low cost and fast-acting, and will employ and expand human capital. We argue that habitat connectivity must be enhanced along latitudinal gradients, but also within the same elevational bands, via a lattice-work corridor system. This is needed to facilitate range shifts for mobile species and evolutionary adaptation for less mobile species. We think that conservation measures within the elevational bands must include conservation-friendly land uses that improve current and future human livelihoods under dynamic conditions. Key components include community involvement, habitat priority-setting, forest landscape restoration, and environmental services payments. Our approach is fundamentally adaptive in that the conservation measures employed are informed by on-the-ground successes and failures and modified accordingly, but are relatively low risk and fast-acting. Our proposal, if implemented, would satisfy tenets of climate-smart conservation, improve the resilience of human and ecological communities, and be a model for other locations facing similar challenges.
\end{abstract}

Key Words: buffer capacity; climate adaptation; community involvement; conservation incentives; Costa Rica; environmental services payments; forest landscape restoration; habitat priority-setting; landscape connectivity; reforestation; resilient ecosystems; resilient livelihoods; riparian zones; tropical mountain ecosystems

\section{INTRODUCTION}

Climate change is threatening biological (Root et al. 2005, Parmesan 2006) and socioeconomic systems (Walker et al. 2004, IPCC 2012) in unprecedented and often unpredictable ways. As a result, conservation managers are challenged to facilitate adaptation and protection of species and ecosystems in highly dynamic and uncertain environments (Lawler et al. 2010). Simultaneously, human communities dependent upon natural resource extraction must adapt their livelihoods (Nakashima et al. 2012). Novel approaches for biological conservation planning under climate change (e.g., Dawson et al. 2011) offer great insight but need broad technical and financial support for on-the-ground implementation, and often do not integrate human needs into proposed solutions. It is imperative to provide resource managers with immediate and viable options that apply "climate-smart" tenets (Hansen et al. 2010), especially where climate change simultaneously affects biodiversity and people.

Successful management plans will increase an ecosystem's resilience, i.e., its ability to absorb disturbance, reorganize, and retain structure and function (Holling 1973) through habitat connectivity (Krosby et al. 2010) and ecological networks (Bennett 2004). Likewise, successful plans will foster socialecological systems that are climate-resilient by having the capacity to buffer climate-related disturbances under conditions in which landowners can self-organize, learn, and take adaptive action (Nelson et al. 2007). To reach these goals, efforts should be aimed at taking advantage of existing incentives, institutional support, and local knowledge in proactive measures that integrate ecological and social-ecological principles. Our aim is to provide practitioners with a practical, scientifically informed framework on how to achieve success despite many hurdles.

Among the ecosystems particularly vulnerable to climate change are tropical forests, where the combined effects of high biodiversity, endemism, and habitat specialization interact to heighten the risk of biodiversity loss (Stork et al. 2009). Tropical mountain communities along steep elevation gradients are likely to be altered as lower-elevation species move upslope (Raxworthy et al. 2008). This may result in lowland biotic attrition (Colwell et al. 2008) and trigger disruptions impossible to predict as assemblages without prior analogs are formed (Williams and Jackson 2007). For some populations, the opportunities for upslope movement may be limited by habitat fragmentation. The ensuing "range-shift gaps" potentially imperil trapped populations (Colwell et al. 2008, Stork et al. 2009). Ongoing climate change thus necessitates management plans that explicitly enhance a population's adaptive capacity, i.e., the ability to respond to current and future environmental changes, thereby promoting ecological resilience and species survival.

Additionally, management plans for tropical mountain landscapes must integrate "resilience thinking" (Folke et al. 2010) for human communities, and intentionally incorporate measures promoting social adaptive capacity, which facilitates the ability to absorb change, organize, learn, and respond adaptively. As 
climatic conditions change, livelihoods on rural, tropical mountains, which generally depend on direct natural resource use, will be affected. It will be important to plan for livelihoods that offer opportunities to shift between or adjust economic activities. To ensure that evolving economic activities do not erode ecosystem structure or function, it will be imperative for conservation practitioners to identify and encourage land uses that support both biodiversity and human livelihoods. However, what lacks is a comprehensive strategy and recommendations that integrate those common interests toward the goal of enhancing the adaptive capacity of the ecological and social-ecological systems under climate change. Our objective is to fill that gap.

We present a conceptual framework for practitioners to assist with enhancing the resilience of ecological and social-ecological systems along a tropical elevational gradient. In our approach, we recognize that financial and technical resources are often highly limited in biodiverse regions, but we circumvent these challenges by capitalizing on existing assets, capabilities, and institutional support. For instance, we have not used modeling approaches such as species distribution or process-based vegetation models because most practitioners are limited by data or technical resources required for on-the-ground applications (Sinclair et al. 2010). Instead, our framework has similarities with the land facets approach (Hunter et al. 1988, Wessels et al. 1999, Beier and Brost 2010), in which local knowledge of watersheds and topography informs conservation priorities. Likewise, we also advocate the use of local knowledge and science-based insights (Reed 2008) in combination with institutional support for incentivizing environmental protection and sustainable land use. We believe that our framework has utility for other systems facing similar challenges. A key to success will be the existence of incentives that operate across time frames to support trial-anderror learning as new livelihoods and conservation methods are tested and improved. Below, we describe our framework in two stages, discussing the biological and then the sociological goals, and how to achieve them.

\section{BIOLOGICAL CORRIDOR FRAMEWORK}

Our overall goal is to create more resilient ecosystems and aid in population persistence through habitat corridors and increasing ecological networks. Ideally, corridor-building for biological conservation goes beyond dispersal and also aids population persistence (Early and Sax 2011). We seek to achieve this through a novel type of habitat corridor that does more than simply link locations; rather, it addresses both dispersal and persistence in the context of climate change. Also, our framework does not require unrealistic expanses of habitat or dramatically different land uses. We propose a lattice-work corridor system that involves land management actions that promote population dispersal and persistence by (1) expanding elevational connectivity along rivers and (2) enhancing connectivity within elevational bands (Fig. 1). The first goal recognizes that some species will disperse toward higher elevations, and more suitable habitat and climatic conditions, as climate change proceeds. The second goal aims to bolster conditions that maintain healthy populations in locally favorable environments, which is critical for less vagile species that cannot easily shift upslope.

We recognize the pros and cons of increasing landscape connectivity through habitat corridors. In some cases, corridors may assist the spread of non-native species (Resasco et al. 2014) and result in competition from species not previously encountered (Foster 2001), causing disruptions in ecological interactions and community processes. However, connectivity within elevational bands may increase effective population sizes and genetic diversity for evolutionary adaptation within species' ranges and at their expanding leading edges (Davis and Shaw 2001). This should reduce pressure for organisms to shift distributions and should reduce biotic attrition and loss of mountaintop species. Also, the overall increase in corridor habitat, although affected by edge effects (Murcia 1995), should provide more favorable microclimate conditions, potentially creating climate change refugia and reducing the rate of drying in upslope regions (Ray et al. 2009).

Fig. 1. Schematic example of a lattice-work corridor system. Elevational connectivity along rivers (blue) facilitates dispersal to higher elevations. Connectivity within an elevational band (light green) facilitates population persistence.

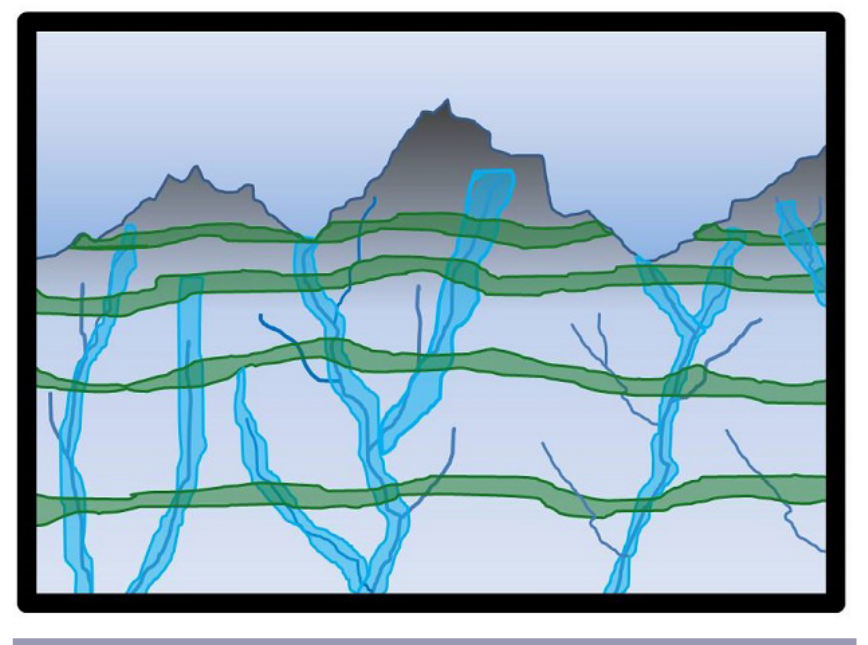

SOCIAL-ECOLOGICAL RESILIENCE FRAMEWORK

Ideally, conservation management plans will facilitate adjustments to human activities that increase social-ecological resilience by fostering three principal features of a resilient system. These are (1) the capacity to absorb disturbances caused by changing climatic conditions without appreciable loss of function, (2) the ability for local residents to organize individual and group networks that offer diverse knowledge and experiences, and (3) the capability to adapt by changing behaviors as climate change proceeds (Folke et al. 2005, Nelson et al. 2007). Managing for social-ecological resilience will mean managing livelihoods and land uses for their buffering capacity, flexibility, and potential to open new opportunities for landowners (Nelson et al. 2007).

In rural communities of tropical developing countries, for which our framework is designed, small-scale farming and ranching are principal economic activities, although they may be supplemented with logging, fishing, or tourism. Residents are likely to be aware of ongoing local climate change because these changes may be affecting crops, livestock, or charismatic species important to tourism. Residents may possess practical knowledge on alternative crops or farming methods, including ones that support 
biodiversity under climate change. However, they may not be aware of the full range of available agricultural options, economic incentives, or institutional support that could potentially enhance their capacity to absorb disturbances and modify their practices as climate change proceeds.

When our social-ecological framework is integrated with latticework corridors, there are numerous opportunities for residents to widen their portfolio of livelihood options that will help them absorb disturbances while also benefiting biodiversity and preserving natural resources. We encourage connections between key actors (e.g., landowners, conservation organizations, agricultural extension agents, etc.) toward the goal of habitat restoration and protection in ways that also mitigate climate change. We consider the short-term economic needs and constraints of local residents, and we promote fast-acting incentives that encourage wise farming alternatives while minimizing risk. We envision a role for conservation nongovernmental organizations (NGOs) as bridging organizations (Folke et al. 2005) that can forge alliances between stakeholders and facilitate the transfer of information about incentives programs, agricultural extension services, and community development projects. We propose outreach to encourage community participation from the outset, and envision a participatory process involving continual monitoring, assessment, and modification of land-use practices as determined by empirical results. In this way, we seek a highly dynamic, forward-looking, and participatory enterprise that continually adapts as well as fosters conditions for future adaptation.

\section{COSTA RICA EXAMPLE}

Here, we consider how to implement our framework in the highly fragmented Pacific slope forests flanking the Tilarán Mountains in the region of Monteverde, Costa Rica. Like other tropical mountain ecosystems (e.g., Madagascar: Raxworthy et al. 2008), this region is undergoing rapid climate change, which is already affecting diverse taxa of cloud forest ecosystems (Pounds et al. 1999, 2006). Human communities are likely to be affected as well because livelihoods are strongly linked to natural resources. Principal economic activities at higher elevations include ecotourism, coffee production, and dairy cattle farming; at lower elevations, residents engage in a mix of dairy and beef cattle ranching and sugarcane production, and, to a lesser extent, pineapple, rice, and mango production. Secondary land-use activities on farms often include subsistence production of beans, corn, plantains, bananas, sugarcane, and citrus, as well as chickens and pigs. Farm sizes range greatly (coffee farms rarely exceed 5 ha, whereas cattle ranches often exceed $20 \mathrm{ha}$ ). The landscape of lower elevations is thus a matrix of mainly pasturelands, dotted with remnant forest patches and small but concentrated human settlements. At higher elevations, there is a large complex of privately protected forest habitat, interspersed with farms and remnant forest patches or windbreaks (Fig. 2). As climate change proceeds, locals are taking note of warmer conditions, more frequent water shortages, as well as unusually harsh rainy periods. Agriculture and ecotourism may have to adapt to the dynamic situation if growing conditions for crops shift or if populations of charismatic species decline. As a result, planning for climate change will require both ecological and social-ecological considerations.
Fig. 2. Because of human use, the remaining forests on the Pacific slope are highly fragmented and disturbed. The foreground shows non-native grasses, which are common in disturbed areas and pastures. The center of the photo shows a small farm with cattle and an area of human settlement. The background of the photo shows forested and deforested hills on the Pacific slope.

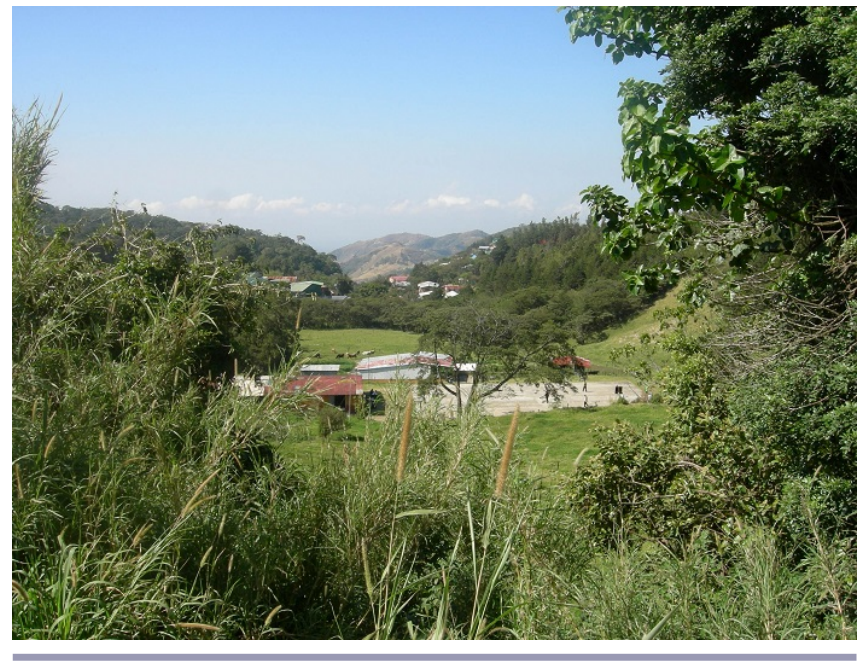

Fortunately, there is a proposal to create a 66,416-ha biological corridor of Pacific slope forest between the Monteverde Reserve Complex in the highlands and the Gulf of Nicoya (Fig. 3; Bell Bird Biological Corridor: http://cbpc.org/publicaciones.html). Like other proposed corridors throughout Costa Rica, this does not explicitly address climate change effects, nor does it employ incentives for implementation (SINAC 2009). Although the proposed corridor incorporates an educational component and includes the well-being of local communities in the mission statement, it does not address specific stakeholder needs or the climate change challenges confronting the Monteverde region. These include upslope colonization of some animal taxa and declines or losses of others (Pounds et al. 1999). Effects may also extend to the numerous and distinctive plant communities. Extensive botanical research has revealed that plant community composition changes in relation to moisture and temperature gradients (Lawton and Dryer 1980, Haber et al. 1996, Haber 2000). In addition, at least 11 climatically distinctive zones are compressed into narrow elevational bands along the mountainside (Holdridge 1966; Fig. 4). To protect species limited to narrow climatic ranges, previous research recommended increasing forest cover and connectivity (Guindon 2000).

Guided by a resilience framework, our specific conservation goals emphasize a shift in priorities from prior proposals and include the protection of 1400 ha of riparian habitat stretching along existing riparian transects, approximately $35 \mathrm{~km}$ in length by 0.1 $\mathrm{km}$ in width. Although currently under protection by the Costa Rican Forestry Law 7575, this riparian habitat has nevertheless suffered degradation. Additionally, we seek to link an equivalent amount of habitat, distributed among the five primary life zones and located on private farms, into a loose ecological network. For this, we propose the use of agroforestry, windbreaks, and forest 
Fig. 3. The proposed Monteverde-Nicoya biological corridor (red) covers 66,416 ha. The high degree of forest fragmentation makes it difficult for species to adapt by shifting their ranges.

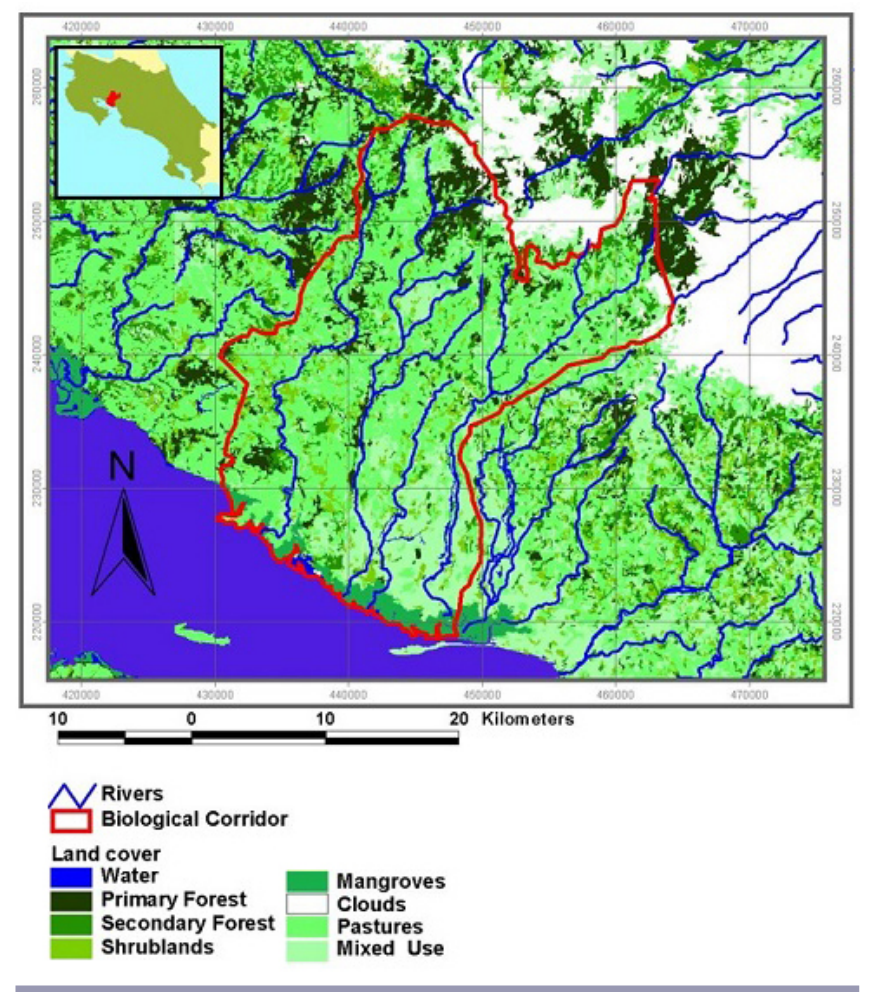

restoration that will not only support biodiversity but also protect water sources for human use, ameliorate the effects of ongoing climate change on currently cultivated crops, and also diversify the range of climate-appropriate crops. To achieve this, we encourage the employment of fast-acting economic incentives that allow experimentation with crops suited for a changing climate and farming methods to mitigate climate change effects. These incentives can effectively buy time for longer term benefits to take effect. We think that lattice-work corridors (Fig. 5) can be very beneficial and can be achieved through a combination of habitat protection, forest landscape restoration, and sustainable land-use practices without requiring major transformations in livelihoods or risk-taking or require unrealistic technological investments.

\section{DESIGNING A LATTICE-WORK CORRIDOR SYSTEM}

\section{Community involvement}

Successful development of a lattice-work corridor and socialecological resilience requires engaging stakeholders from the very outset because this enriches mutual understanding and improves management plans and implementation (Stringer et al. 2006). The principal stakeholders, in this case residents and landowners of the Monteverde region, largely determine land-use activities for the region; thus, their interests and needs will set the basic parameters for engagement and conservation priority-setting. It will be critical to allow stakeholders to articulate their interests and needs, and then seek overlap with requirements for
Fig. 4. There are 11 climatically distinctive zones (life zones; Holdridge 1966), compressed into often narrow elevational bands in the $35-\mathrm{km}$ corridor. The elevational bands are characterized by different combinations of temperature and precipitation conditions and tend to harbor different plant assemblages.

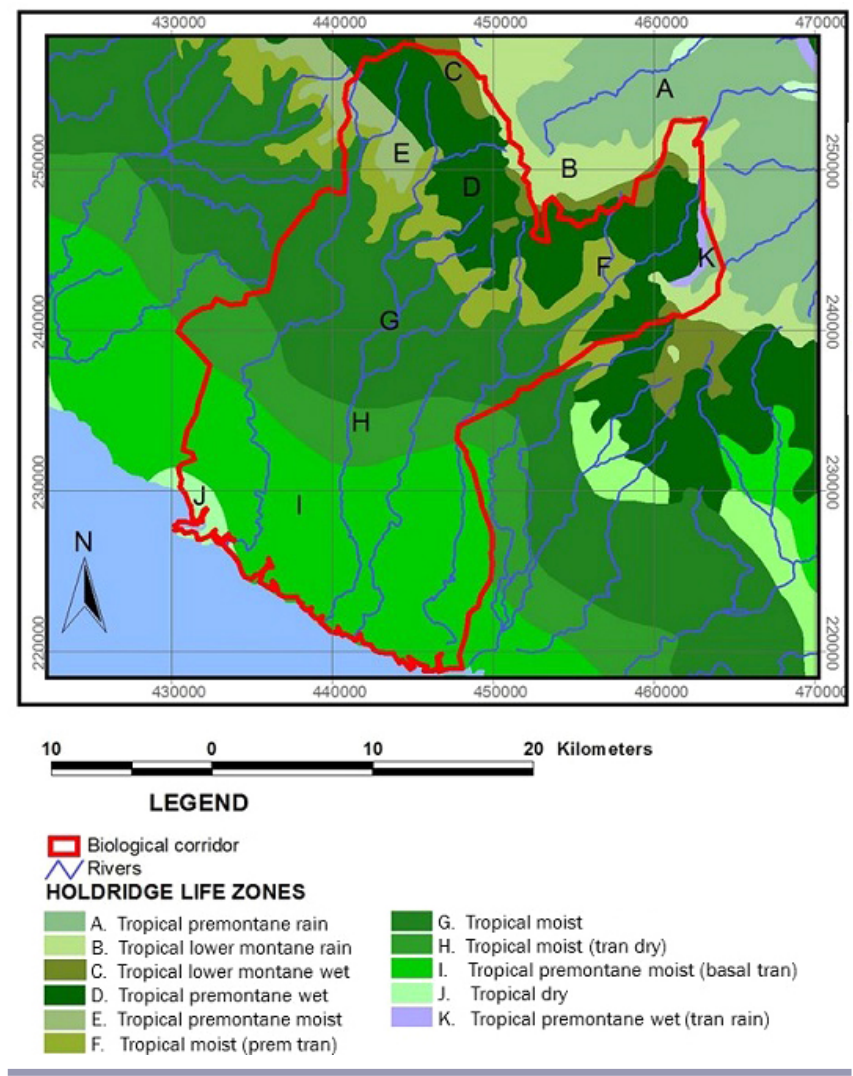

biodiversity protection. The overall goal should be to involve stakeholders in participatory processes toward creating a more resilient system, i.e., one that will expand the stakeholders' capacity to absorb disturbances, enhance their ability to selforganize, and create conditions that facilitate iterative learning and modification of land-use activities (Olsson et al. 2004).

We stress the importance of offering learning and adaptation opportunities, specifically surrounding land-use activities that complement biodiversity protection. Conservation professionals could use outreach events to identify individuals who possess valuable ecological knowledge that may be under threat of loss (Harvey et al. 2008), as well as individuals who are willing and able to share experiences in sustainable land-use practices. To determine how best to integrate local environmental knowledge with scientific knowledge (Raymond et al. 2010), successful examples of participatory design processes will be essential (Reed 2008).

Beyond planning for resilience-building, it is critical that there be regular two-way communication throughout the implementation phase (Stringer et al. 2006). This should include informationsharing on incentives and agricultural outreach programs, plus 
Fig. 5. To plan for climate change, we suggest implementing a lattice-work corridor system (blue and yellow) within the proposed Monteverde-Nicoya biological corridor. A first priority should be creating forest connectivity along riparian areas (blue), and second will be creating connectivity within elevational bands (yellow) for less mobile species to facilitate population persistence.

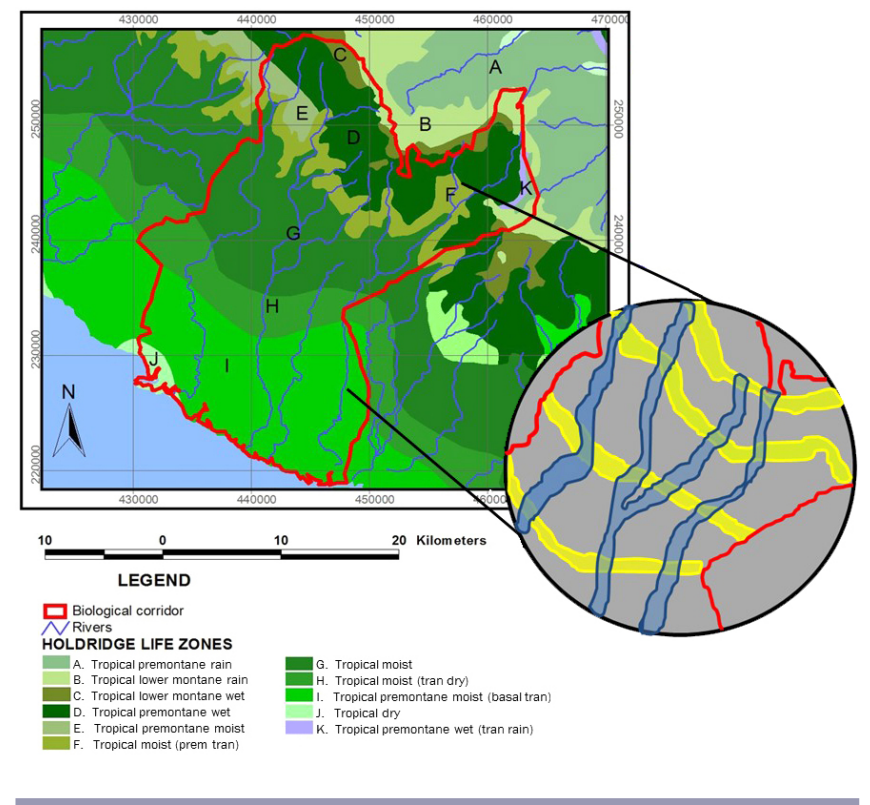

networking between scientists and local experts. Plans should include mechanisms for community involvement in subsequent monitoring and evaluation of projects. Actively involving locals in the monitoring and evaluation of projects will ensure bilateral communication and sustain engagement and investment. If landowners participating in the Monteverde lattice-work corridor project were paid or otherwise encouraged to undertake the monitoring responsibility, it may increase their overall investment and commitment. For the implementation of monitoring to be successful, community education and funding would be helpful (Townsend 2011).

\section{Habitat priority-setting}

To build a lattice-work corridor system in the Monteverde region, we recommend three focal priority habitats for protection and restoration: riparian habitats, forest patches, and farms. The first step would be to improve riverine forest corridors (Hannah et al. 2008). Costa Rican forestry law 7575 has prevented some, but not all, habitat degradation and loss along riparian buffer zones, thus necessitating forest restoration in select riparian areas. Riverine habitats that are highly degraded should be assigned high priority status for immediate restoration.

The second step of our plan addresses improving connectivity through forest patches and farms within elevational bands. Because most property in this region is held by small landowners who farm or raise livestock, this will require a participatory process that seeks the intersection of activities serving both conservation goals and community livelihoods. Emphasis should be placed on how well a farm's features can serve as a link between forest patches across the landscape. Priority should be placed on involving stakeholders with whom there exists the highest potential for positive engagement, coupled with healthy forest patches, springs and streams, and actual or potential production practices that support conservation efforts, such as agroforestry, permaculture, windbreaks, or live fences (Chacón León and Harvey 2006, Harvey and González Villalobos 2007).

\section{Forest landscape restoration for resilient ecosystems and livelihoods}

Because of the high degree of Pacific slope deforestation in the Monteverde region, habitat restoration will be an important component in creating the corridor. We advocate forest landscape restoration, which seeks to benefit both biodiversity and human livelihoods (Newton et al. 2012) in ways that increase socialecological resilience. Around rivers and springs, the emphasis should be directed toward reforesting and rehabilitating degraded areas. By expanding riparian corridors and restoring forests around springs, freshwater resources may be better protected for humans and wildlife into the future, upslope dispersal will be facilitated, and there will be an increase in overall habitat within elevational bands. While Costa Rican forestry law 7575 prohibits extractive practices and requires buffer forest around water sources ( $50 \mathrm{~m}$ in steep terrain and $10-15 \mathrm{~m}$ in flat terrain), the reality is that tree-cutting occurs and cattle often enter. We therefore also urge better enforcement of the law, and the revitalization of the former "Forest on Farms" project of the Monteverde Conservation League, which supplied fence posts and wire to exclude livestock from forest patches around springs and streams (Burlingame 2000).

In the case of forest landscape restoration for farms, we recognize that the priority is the resilience of livelihoods under climate change that secondarily sustain biodiversity. Thus, restoration should (1) augment the ability of a landowner to absorb disturbances such as crop failure or market shifts, (2) afford opportunities for communities to organize themselves, and (3) involve capacity-building so that stakeholders can engage in iterative learning. Some valuable restoration activities could thus include increasing overall tree coverage on farms in ways that buffer climate disruptions while introducing potential new crops. For instance, livelihood resilience can be enhanced by (1) planting crop varieties and trees able to withstand intensified drought, resist fungal infections, and thwart erosion caused by progressively more severe wind and rain storms; (2) diversifying the range of fruit trees and shade-tolerant cash crops to withstand market shocks and provide novel market opportunities; and (3) planting shade trees for people and livestock to ameliorate rising air temperatures. Livelihood resilience can also be developed by expanding common and familiar practices. These include planting windbreaks and live fences to combat erosion, enrich soil, or supply shade or food for livestock or humans (Haber et al. 1996, Zuchowski 2007). If planned carefully, windbreaks and live fences offer secondary benefits to conservation, such as food resources and connections between forest patches for wildlife in Monteverde (Harvey and Haber 1998, Nielsen and DeRosier 2000) as well as other tropical locations (Dawson et al. 2013). Other current practices such as agroforestry could be diversified by experimenting with more varieties of understory crops or by incorporating shade tree species with diverse commercial 
products, from food to fiber. If such agroforestry systems were planted near riparian forest corridors, the crops may benefit from ecosystem services such as pollination, and, to some extent, they may serve to widen the riparian habitat available to wildlife.

\section{Tree species selection}

Because reforestation and agroforestry play key roles in creating resilient systems, a central concern will be tree species selection. Criteria should include contribution to community diversity and ecosystem function, including nutrient and water cycles, energy flow, and other benefits such as food for humans and wildlife and shade for livestock. When possible, tolerance for changing abiotic conditions should be assessed to anticipate whether a candidate species will adapt and persist in spite of directional climate shifts (Seastedt et al. 2008). This is especially salient for our system because many trees of the northern Pacific slopes require specific climatic conditions (Haber et al. 1996).

Consideration should be given to well-known non-natives that have limited negative effects and well-documented benefits such as timber species that can provide shade for understory species (e.g., Lugo 2009) and economic benefits to the landowner. However, community input would be especially needed in this area because previous plantings of non-natives reveal relatively limited ecological benefits. For instance, although windbreaks of the non-native tree species Cupressus lusitanica, Casuarina equisetifolia, and Croton niveus are used by birds for movement between forest patches and for depositing seeds (Harvey 2000a, Nielsen and DeRosier 2000), they do not support frugivorous birds with fruit (Haber et al. 1996). Also, whereas these windbreaks support more native tree seedlings than do pastures, native tree seedling densities are low (Harvey 2000b). Likewise, the density and diversity of epiphytic orchids are low compared to those harbored on native tree species (K. Masters, personal observation), perhaps because orchid germination rates on nonnative host species are lower (Kartzinel et al. 2013). In general, the trend in Monteverde now is to replace non-native species with native species (K. Masters, personal observation).

In selecting native tree species, the most cautious approach is to choose species of the same elevational band that are more tolerant of hot, dry, or highly variable conditions, such as Citharexylum costaricensis (Verbenaceae), an early successional species (Haber et al. 1996). The Costa Rica Conservation Foundation (http://66.147.244.232/ fccmonte/category/bellbird-conservationproject/reforestation/) has successfully adopted this tactic when reforesting abandoned pastures on the Pacific slopes, which are hotter and drier than nearby forest. Another low-risk approach is to select species whose ranges extend across elevational bands, e.g., Inga punctata (Fabaceae) and Nectandra salicina (Lauraceae) (P. Townsend, personal observation). A riskier and more controversial course is to assist colonization by planting species from lower elevations above their range (Hoegh-Guldberg et al. 2008). For instance, Montanoa guatemalensis (Asteraceae) has been used extensively for windbreaks in the Monteverde region since the 1980s (Zuchowski 2007), extending its natural elevational range $(700-1200 \mathrm{~m})$ by $300 \mathrm{~m}$ without apparent negative ecological consequences. Assisted colonization merits consideration because lower elevation species may have higher survival rates under changing environmental conditions and thus may create resilient habitats that mitigate biodiversity and socioeconomic losses.

\section{IMPLEMENTATION, INCENTIVES, AND INSTITUTIONAL SUPPORT FOR LATTICE-WORK CORRIDORS}

Implementation of a lattice-work corridor in Monteverde, or along other tropical mountains, may require that landowners adopt potentially unfamiliar or costly changes to agricultural practices. We recommend that the Costa Rican government and NGOs provide agricultural research and extension services and promote market development to expand the range of options for climate-resilient crops. These opportunities should also aim to educate community members about forest protection, habitat restoration, and climate change, and also facilitate informationsharing on economic incentives for conservation and sustainable land-use initiatives. Likewise, we advise conservation professionals to facilitate connections between landowners and government or NGO programs that incentivize experimentation with agricultural practices and new crops so that farmers can learn and modify practices. In this sense, conservation NGOs can play a critical role as bridging organizations (Folke et al. 2005).

Fortunately, in Costa Rica, institutions such as the Ministry of Agriculture, the Centro Agrónomo Tropical de Investigación y Enseñaza (Tropical Agricultural Research and Higher Education Center), the Instituto Nacional de Aprendizaje (National Learning Institute), and national cooperatives support agriculturalists with research, education, and market development. Further, a special government program through the Fondo Nacional de Financiamiento Forestal (National Forestry Financing Fund) offers promising opportunities to incentivize landowner participation, which yield nearly immediate economic benefits. These could jump-start adaptive activities that will provide benefits over the longer term while landowners, agriculturalists, and conservationists learn which practices work best under dynamic climatic conditions.

\section{Fast-acting and available incentives}

In a number of tropical countries, nearly immediate and direct economic benefits to landowners are supplied through environmental service payments programs (ESP programs; Wunder 2007, Swallow et al. 2009). In Costa Rica, landowners are compensated by placing their land under a legal category of forest protection, regeneration, or agroforestry, and receive direct payments for renewable contracts (3-, 5-, or 10-yr periods). For instance, Costa Rican law (Decreto 36935, 2012) specifies that participants in the program are paid for each tree added to an agroforestry system, with a higher amount allocated for native species ( $\$ 1.95$ vs. $\$ 1.30$ USD per tree for a 3-yr period).

Stakeholders engaged in ecotourism may benefit from planting native species to attract wildlife, whereas owners of large areas or farms may be more interested in the economic benefits from the ESP or planting high-value species for agroforestry. Cattle ranchers and farmers of particular crops may benefit from windbreaks and shade. Regardless, direct payments could jumpstart a region-wide effort to plant trees around springs, expand habitat in forest remnants and windbreaks, and experiment with new tree crops, while simultaneously placing the habitat under legal protection. Once protected, this habitat could form the building blocks for an inter-connected system of corridors and patches leading to the success of the lattice-work corridor system. This is a reasonable goal because the ESP program prioritizes contracts for properties in biological corridors or with hydrological importance (Decreto 36935, 2012). 
There are hurdles to making ESP a viable incentive for regionwide conservation. Landowners may be unaware of the program (Townsend 2011), may not meet the requirements, or may not be willing to complete the complicated application process, which requires a land management plan (Decreto 36935, 2012). Further, with the number of applicants surpassing available funds, there are no guarantees that applicants will be awarded funds. Even if approved, the monetary value of the payments may not equal or surpass alternative land uses. Lastly, the program favors applicants who have held contracts previously over those who have not (Decreto 36935, 2012).

Some of these challenges could be partly ameliorated if an organization were to facilitate the application process. A model organization could be the Foundation for Sustainable Development of the Central Volcanic Range (FUNDECOR), an NGO that facilitates the ESP application in the Central Valley area of Costa Rica. FUNDECOR is effective at lobbying the National Fund for Forest Financing (FONAFIFO), which administers the ESP program, for support of its applicants. A Pacific slope organization should seek to achieve FONAFIFO support as well. Currently, there is no such organization, but it could potentially be funded through the REDD+ program, which funds projects to increase carbon sinks through reforestation and to improve rural livelihoods (Groom and Palmer 2012).

\section{Longer term incentives}

Not all incentives can operate on the relatively short time frame of the ESP program. For instance, tree planting for the purposes of protecting springs, creating windbreaks, increasing cover for shade crops, or for fruit production, will supply benefits after some period of years (Dawson et al. 2013). Nevertheless, the benefits are real and can improve farming economics. In Monteverde, many residents are familiar with the benefits accrued from past regional programs that succeeded in planting $>500,000$ trees to create $>180 \mathrm{~km}$ of windbreaks and protect springs on private property (Burlingame 2000). Farmers are well aware that windbreaks protect crops and cattle from high winds and soil loss, as well as conserve water sources and provide habitat for birds and other wildlife (Burlingame 2000). Whereas many of the windbreaks were planted with non-native tree species, local native species offer viable options for live fences and windbreaks that contribute positively to ecosystem functioning (Zuchowski 2007). If a revitalized windbreak program were to supply native trees at little or no cost, or if farmers were compensated through the ESP program, their participation could be great. These windbreaks could begin to create the lattice-work corridors in areas with little current forest cover.

A landowner's familiarity with successful examples of employing nontraditional crops and farming methods may encourage experimentation and patience for longer term payoffs. For instance, coffee has historically been a very important local crop at higher elevations and is often grown in patches surrounded by or interspersed with native trees in agroforestry plantations. Farmers may be willing to experiment with agroforestry at middle or lower elevations by interspersing trees as fruit cash crops (e.g., avocados, citrus, mangos, cashew, and macadamia) or as a timber crop (e.g., Cordia aliodora). These could be shade trees for cacao, which has recently been introduced to Monteverde near $1000 \mathrm{~m}$ and sets fruit (K. Masters, personal observation). Also, while few such crops are native, they contribute to the resilience of the agroecosystem by increasing livelihood diversity, broadening crop diversity, and performing important ecosystem services. If such species were available at subsidized prices or if farmers were compensated by ESP, willingness to plant them should increase.

Other long-term incentives could target the tourism industry to broaden the range of markets. For instance, wood carving for souvenirs is an important local industry that can allow artisans to capture a higher profit margin by selling a value-added product. The industry can promote climate-friendly practices, as carbon is locked up long-term in the carved wood (Pandey 2002), provided that the wood is sourced from fallen limbs or sustainably harvested from timber plantations as part of the lattice-work corridor. A critical component to ensure sustainability would be third-party certification, such as Forest Stewardship Council, that can reveal the chain of custody (National Research Council 2010). If ESP programs incentivized planting native timber species, farmers may be encouraged to await the long-term benefits of this familiar industry, even if paperwork encumbered the certification process.

\section{CONCLUSIONS}

In our lattice-work framework, we aspire to increase ecological and social-ecological resilience in tropical mountain ecosystems experiencing rapid climate change. In places like Monteverde, which are highly dependent on natural resources for ecotourism and agriculture and simultaneously harbor high species richness, a lattice-work corridor can benefit multiple stakeholders and biodiversity. Our framework provides mechanisms for population persistence and dispersal and promotes small-scale connectivity initiatives that can be integrated into the agricultural landscape (Harvey et al. 2008). The framework can jump-start conservation programs that serve both human and nonhuman needs while taking advantage of existing economic incentives that serve immediate stakeholder needs. This is in contrast to creating corridors through large-scale reforestation and habitat preservation, which focus less on human needs and have higher costs. The incentives employed for the lattice-work offer a realistic mechanism toward the goal of protecting riparian habitat across elevations and restoring an equal amount of habitat within elevational bands, while also providing an agricultural landscape that meets the livelihood needs and interests of local residents. Further, the framework capitalizes on existing institutional support and local and scientific knowledge, but it does not require great technological or financial investments.

By using the lattice-work framework to increase ecological resilience, opportunities are also created for enhanced socialecological resilience (e.g., Thompkins and Adger 2004). In integrating both resilience frameworks, resource-dependent livelihoods should be better able to absorb and respond to market and environmental disturbances through diversified and climateappropriate crop portfolios. Additionally, resilience in both the ecological and social-ecological spheres will increase from practices that expand tree coverage by mitigating temperature change and protecting water resources. By involving local stakeholders in a highly participatory process, it should be possible to identify overlap between the needs for livelihoods and biodiversity. The likelihood of successful implementation should increase because of the emphasis on incremental and incentivized 
measures that are monitored and modified by the stakeholders themselves. Thus, it should be possible for communities to enrich and restore the natural capital on which they depend (Harris et al. 2006).

In implementing our framework, we strive to apply all four tenets of climate-smart conservation (Hansen et al. 2010) toward a strategy of adaptive conservation planning. Our proposal applies the tenet "reduce nonclimate stress" by encouraging reforestation with native species toward the goal of lowering edge effects and raising overall forest cover in ways that promote dispersal and population persistence. By encouraging extensive reforestation and agroforestry, we are striving to meet the tenet to "reduce the rate and extent of climate change." Even at small scales, the restoration of tropical forests can contribute to carbon sequestration and climate change mitigation.

For the climate-smart tenets of "protect space" and "use adaptive management" (Hansen et al. 2010), we think that the involvement of local people from the outset is central to the success of climatesmart conservation and the implementation of the lattice-work corridor. We urge the adoption of our framework for socialecological resilience that increases the buffer capacity of farms and protects livelihoods into the future in ways that also protect space (i.e., habitat). We appreciate that landowners need incentives and assurances before altering land-use practices and that they possess highly relevant knowledge and experience that can be used toward adaptive management (Berkes et al. 2000). We advise conservation managers to partner with landowners who are interested in increasing tree coverage in agroforestry systems or restoring habitat, and to assist in establishing monitoring programs to evaluate progress. This process will help to weave corridors, build buffer zones between forest patches, and rehabilitate rivers and springs. The consequence will be increased habitat connectivity (Krosby et al. 2010), the creation of ecological networks (Bennett 2004), and will essentially satisfy the tenet to protect space (Hansen et al. 2010). All of these enhance conservation efforts under climate change. Further, the highly participatory partnership that we prescribe should enhance the capacity of landowners to make adaptive adjustments as climate change proceeds.

We concur with Hansen et al. (2010) that we may need to "build the bicycle while riding it," that is, devise and implement novel reforestation and land-use management practices as we learn from successes and failures in the field. However, this should not deter efforts. In the process, human and social capital is built, and this will empower communities with adaptive management skills. We understand that this will require extensive outreach, but the incentives program increases the likelihood of local participation and rapid results, and the longer term benefits are potentially great for biodiversity and landowners alike.

Although Costa Rica in general and Monteverde in particular may be best-case scenarios for testing and implementing these frameworks, other locations and communities in tropical, developing countries may have assets and incentives that can similarly be tapped. This includes other locations in Central America, the tropical Andes, and the tropical mountain regions of Africa. The general lack of technical or financial capital should not deter conservation practitioners from seeking and exploiting other kinds of capital such as local knowledge to make the best decisions possible. What may be of overriding importance in protecting biodiversity and resource-dependent livelihoods in a highly dynamic context is creativity in identifying and tapping existing capabilities and assets, coupled with a willingness to embrace learning through action.

Responses to this article can be read online at: http://www.ecologyandsociety.org/issues/responses. $\mathrm{php} / 7324$

\begin{abstract}
Acknowledgments:
M. Groom, J. Lawler, N. Nadkarni, J. Hoffman, S. Riechard, and the Groom and Lawler labs provided helpful comments on earlier drafts. Suggestions from three anonymous reviewers also greatly improved the manuscript. C. Gomez assisted with map making. Funding for $P$. A. Townsend came from the United States Environmental Protection Agency (EPA) under the Science to Achieve Results (STAR) Graduate Fellowship Program. EPA has not officially endorsed this publication, and these views may not reflect those of EPA. Additional funding for P. A. Townsend came from the National Garden Club and the Groom lab.
\end{abstract}

\section{LITERATURE CITED}

Beier, P., and B. Brost. 2010. Use of land facets to plan for climate change: conserving the arenas, not the actors. Conservation Biology 24(3):701-710. http://dx.doi.org/10.1111/j.1523-1739.2009.01422. $\underline{\mathrm{X}}$

Bennett, G. 2004. Integrating biodiversity conservation and sustainable use: lessons learned from ecological networks. IUCN, Gland, Switzerland and Cambridge, UK.

Berkes, F., J. Colding, and C. Folke. 2000. Rediscovery of traditional ecological knowledge as adaptive management. Ecological Applications 10:1251-1262. http://dx.doi.org/10.1890/1051-0761 (2000)010[1251:ROTEKA]2.0.CO;2

Burlingame, L. J. 2000. Conservation in the Monteverde zone: contributions of conservation organizations. Pages 351-375 in N. M. Nadkarni and N. T. Wheelwright, editors. Monteverde: ecology and conservation of a tropical cloud forest. Oxford University Press, New York, New York, USA.

Chacón León, M., and C. A. Harvey. 2006. Live fences and landscape connectivity in a neotropical agricultural landscape. Agroforestry Systems 68(1):15-26. http://dx.doi.org/10.1007/ $\underline{\mathrm{s} 10457-005-5831-5}$

Colwell, R. K., G. Brehm, C. L. Cardelús, A. C. Gilman, and J. T. Longino. 2008. Global warming, elevational range shifts, and lowland biotic attrition in the wet tropics. Science 322:258-261. http://dx.doi.org/10.1126/science.1162547

Davis, M. B., and R. G. Shaw. 2001. Range shifts and adaptive responses to quarternary climate change. Science 292:673-679. http://dx.doi.org/10.1126/science.292.5517.673

Dawson, I. K., M. R. Guariguata, J. Loo, J. C. Weber, A. Lengkeek, D. Bush, J. Cornelius, L. Guarino, R. Kindt, C. Orwa, J. Russell, and R. Jamnadass. 2013. What is the relevance of 
smallholders' agroforestry systems for conserving tropical tree species and genetic diversity in circa situm, in situ and ex situ settings? Biodiversity and Conservation 22(2):301-324. http://dx. doi.org/10.1007/s10531-012-0429-5

Dawson, T. P., S. T. Jackson, J. I. House, I. C. Prentice, and G. M. Mace. 2011. Beyond predictions: biodiversity conservation in a changing climate. Science 332:53-58. http://dx.doi.org/10.1126/ science. 1200303

Decreto 36935. 2012. Pago de servicios ambientales para el año 2012. Ministra de Ambiente, Energía y Telecomunicaciones, San José, Costa Rica. [online] URL: http://www.pgrweb.go.cr/scij/ Busqueda/Normativa/Normas/nrm articulo.aspx?param1= NRA\&nValor $1=1 \&$ nValor $2=71850 \& n$ Valor $3=87371 \& n$ Valor $5=-$ 2\&strTipM=FA.

Early, R., and D. F. Sax. 2011. Analysis of climate paths reveals potential limitation on species range shifts. Ecology Letters 14 (11):1125-1133. http://dx.doi.org/10.1111/j.1461-0248.2011.01681. $\underline{\mathrm{X}}$

Folke, C., S. R. Carpenter, B. Walker, M. Scheffer, T. Chapin, and J. Rockström. 2010. Resilience thinking: integrating resilience, adaptability and transformability. Ecology and Society 15(4): 20. [online] URL: http://www.ecologyandsociety.org/vol15/iss4/ art20/.

Folke, C., T. Hahn, P. Olsson, and J. Norberg. 2005. Adaptive governance of social-ecological systems. Annual Review of Environment and Resources 30:441-473. http://dx.doi.org/10.1146/ annurev.energy.30.050504.144511

Foster, P. 2001. The potential negative impacts of global climate change on tropical montane cloud forests. Earth-Science Reviews 55(1-2):73-106. http://dx.doi.org/10.1016/S0012-8252(01)00056-3

Groom, B., and C. Palmer. 2012. REDD+ and rural livelihoods. Biological Conservation 154:42-52. http://dx.doi.org/10.1016/j. biocon.2012.03.002

Guindon, C. F. 2000. The importance of Pacific slope forest for maintaining regional biodiversity. Pages 435-437 in N. M. Nadkarni and N. T. Wheelwright, editors. Monteverde: ecology and conservation of a tropical cloud forest. Oxford University Press, New York, New York, USA.

Haber, W. A. 2000. Plants and vegetation. Pages 39-69 in N. M. Nadkarni and N. T. Wheelwright, editors. Monteverde: ecology and conservation of a tropical cloud forest. Oxford University Press, New York, New York, USA.

Haber, W. A., W. Zuchowski, and E. Bello. 1996. An introduction to cloudforest trees: Monteverde, Costa Rica. La Nacion, San Jose, Costa Rica.

Hannah, L., D. Radhika, P. P. Lowry II, S. Andelman, M. Andrianarisata, L. Andriamaro, A. Cameron, R. Hijmans, C. Kremen, J. MacKinnon, H. H. Randrianasolo, S. Andriambololonera, A. Razafimpahanana, H. Randriamahazo, J. Randrianarisoa, P. Razafinjatovo, C. Raxworthy, G. E. Schatz, M. Tadross, and L. Wilmé. 2008. Climate change adaptation for conservation in Madagascar. Biology Letters 4:590-594. http://dx.doi.org/10.1098/ $\underline{\mathrm{rsbl}} .2008 .0270$
Hansen, L., J. Hoffman, C. Drews, and E. Mielbrect. 2010. Designing climate-smart conservation: guidance and case studies. Conservation Biology 24(1):63-69. http://dx.doi.org/10.1111/ j.1523-1739.2009.01404.X

Harris, J. A., R. J. Hobbs, E. Higgs, and J. Aronson. 2006. Ecological restoration and global climate change. Restoration Ecology 14(2):170-176. http://dx.doi.org/10.1111/j.1526-100X.2006.00136. $\underline{\mathrm{X}}$

Harvey, C. A. 2000a. Windbreaks enhance seed dispersal into agricultural landscapes in Monteverde, Costa Rica. Ecological Applications 10(1):155-173. http://dx.doi.org/10.1890/1051-0761 (2000)010[0155:WESDIA]2.0.CO;2

Harvey, C. A. 2000b. Colonization of agricultural windbreaks by forest trees: effects of connectivity and remnant trees. Ecological Applications 10(6):1762-1773. http://dx.doi.org/10.1890/1051-0761 (2000)010[1762:COAWBF]2.0.CO:2

Harvey, C. A., and J. A. González Villalobos. 2007. Agroforestry systems conserve species-rich but modified assemblages of tropical birds and bats. Biodiversity and Conservation 16 (8):2257-2292. http://dx.doi.org/10.1007/s10531-007-9194-2

Harvey, C. A., and W. A. Haber. 1998. Remnant trees and the conservation of biodiversity in Costa Rican pastures. Agroforestry Systems 44(1):37-68. http://dx.doi.org/10.1023/ A:1006122211692

Harvey, C. A., O. Komar, R. Chazdon, B. G. Ferguson, B. Finegan, D. M. Griffith, M. Martínez-Ramos, H. Morales, R. Nigh, L. Soto-Pinto, M. Van Bruegel, and M. Wishnie. 2008. Integrating agricultural landscapes with biodiversity conservation in the Mesoamerican hotspot. Conservation Biology 22(1):8-15. http://dx.doi.org/10.1111/j.1523-1739.2007.00863.x

Hoegh-Guldberg, O., L. Hughes, S. McIntyre, D. B. Lindenmayer, C. Parmesan, H. P. Possingham, and C. D. Thomas. 2008. Assisted colonization and rapid climate change. Science 321:345-346. http://dx.doi.org/10.1126/science.1157897

Holdridge, L. R. 1966. The life zone system. Adansonia 6:199-203.

Holling, C. S. 1973. Resilience and stability of ecological systems. Annual Review of Ecology and Systematics 4:1-23. http://dx.doi. org/10.1146/annurev.es.04.110173.000245

Hunter, M. L. Jr., G. L. Jacobson Jr., and T. Webb III. 1988. Paleoecology and the coarse-filter approach to maintaining biological diversity. Conservation Biology 2(4):375-385. http://dx. doi.org/10.1111/j.1523-1739.1988.tb00202.x

IPCC. 2012. Managing the risks of extreme events and disasters to advance climate change adaptation. A special report of Working Groups I and II of the Intergovernmental Panel on Climate Change. C. B. Field, V. Barros, T. F. Stocker, D. Qin, D. J. Dokken, K. L. Ebi, M. D. Mastrandrea, K. J. Mach, G. K. Plattner, S. K. Allen, M. Tignor, and P. M. Midgley, editors. Cambridge University Press, Cambridge, UK. [online] URL: http://ipcc-wg2.gov/ SREX/report/.

Kartzinel, T. R., D. W. Trapnell, and R. P. Shefferson. 2013. Critical importance of large native trees for conservation of a rare Neotropical epiphyte. Journal of Ecology 101(6):1429-1438. http://dx.doi.org/10.1111/1365-2745.12145 
Krosby, M., J. Tewksbury, N. M. Haddad, and J. Hoekstra. 2010. Ecological connectivity for a changing climate. Conservation Biology 24(6):1686-1689. http://dx.doi.org/10.1111/j.1523-1739.2010.01585. $\underline{x}$

Lawler, J. J., T. H. Tear, C. Pyke, M. R. Shaw, P. Gonzalez, P. Kareiva, L. Hansen, L. Hannah, K. Klausmeyer, A. Aldous, C. Bienz, and S. Pearsall. 2010. Resource management in a changing and uncertain climate. Frontiers in Ecology and the Environment 8:35-43. http://dx.doi.org/10.1890/070146

Lawton, R., and V. Dryer. 1980. The vegetation of the Monteverde Cloud Forest Reserve. Brenesia 18:101-116.

Lugo, A. E. 2009. The emerging era of novel tropical forests. Biotropica 41(5):589-591. http://dx.doi.org/10.1111/ j.1744-7429.2009.00550.x

Murcia, C. 1995. Edge effects in fragmented forests: implications for conservation. Trends in Ecology and Evolution 10(2):58-62. http://dx.doi.org/10.1016/S0169-5347(00)88977-6

Nakashima, D. J., K. Galloway McLean, H. D. Thulstrup, A. Ramos Castillo, and J. T. Rubis. 2012. Weathering uncertainty: traditional knowledge for climate change assessment and adaptation. UNESCO, Paris, France, and United Nations University, Darwin, Australia. [online] URL: http://www.unesco. org/new/en/natural-sciences/priority-areas/sids/resources/pubs-singleview-sids/news/weathering uncertainty traditional knowledge for_climate_change_assessment_and_adaptation/\#.VNPJMS64E24.

National Research Council. 2010. Certifiably sustainable?: The role of third-party certification systems. Report of a workshop. National Academies Press, Washington, D.C., USA. [online] URL: http://www.nap.edu/catalog/12805.html.

Nelson, D. R., W. N. Adger, and K. Brown. 2007. Adaptation to environmental change: contributions of a resilience framework. Annual Review of Environment and Resources 32:395-419. http:// dx.doi.org/10.1146/annurev.energy.32.051807.090348

Newton, A. C., R. F. del Castillo, C. Echeverría, D. Geneletti, M. González-Espinosa, L. R. Malizia, A. C. Premoli, J. M. Rey Benayas, C. Smith-Ramírez, and G. Williams-Linera. 2012. Forest landscape restoration in the drylands of Latin America. Ecology and Society 17(1): 21. http://dx.doi.org/10.5751/ES-04572-170121

Nielsen, K., and D. DeRosier. 2000. Windbreaks as corridors for birds. Pages 448-449 in N. M. Nadkarni and N. T. Wheelwright, editors. Monteverde: ecology and conservation of a tropical cloud forest. Oxford University Press, New York, New York, USA.

Olsson, P., C. Folke, and F. Berkes. 2004. Adaptive comanagement for building resilience in social-ecological systems. Environmental Management 34(1):75-90. http://dx.doi.org/10.1007/s00267-003-0101-7

Pandey, D. N. 2002. Carbon sequestration in agroforestry systems. Climate Policy 2(4):367-377. http://dx.doi.org/10.3763/cpol.2002.0240

Parmesan, C. 2006. Ecological and evolutionary responses to recent climate change. Annual Review of Ecology, Evolution, and Systematics 37:637-669. http://dx.doi.org/10.1146/annurev. ecolsys.37.091305.110100

Pounds, J. A., M. R. Bustamante, L. A. Coloma, J. A. Consuegra, M. P. L. Fogden, P. N. Foster, E. La Marca, K. L. Masters, A.
Merino-Viteri, R. Puschendorf, S. R. Ron, G. A. SánchezAzofeifa, C. J. Still, and B. E. Young. 2006. Widespread amphibian extinctions from epidemic disease driven by global warming. Nature 439:161-167. http://dx.doi.org/10.1038/nature04246

Pounds, J. A., M. P. L. Fogden, and J. H. Campbell. 1999. Biological response to climate change on a tropical mountain. Nature 398:611-615. http://dx.doi.org/10.1038/19297

Raxworthy, C. J., R. G. Pearson, N. Rabibisoa, A. M. Rakotondrazafy, J.-B. Ramanamanjato, A. P. Raselimanana, S. $\mathrm{Wu}$, R. A. Nussbaum, and D. A. Stone. 2008. Extinction vulnerability of tropical montane endemism from warming and upslope displacement: a preliminary appraisal for the highest massif in Madagascar. Global Change Biology 14(8):1703-1720. http://dx.doi.org/10.1111/j.1365-2486.2008.01596.x

Ray, D. K., R. A. Pielke Sr., U. S. Nair, R. M. Welch, and R. O. Lawton. 2009. Importance of land use versus atmospheric information verified from cloud simulations from a frontier region in Costa Rica. Journal of Geophysical Research: Atmospheres 114: D08113. http://dx.doi.org/10.1029/2007JD009565

Raymond, C. M., I. Fazey, M. S. Reed, L. C. Stringer, G. M. Robinson, and A. C. Evely. 2010. Integrating local and scientific knowledge for environmental management. Journal of Environmental Management 91(8):1766-1777. http://dx.doi. org/10.1016/j.jenvman.2010.03.023

Reed, M. S. 2008. Stakeholder participation for environmental management: a literature review. Biological Conservation 141 (10):2417-2431. http://dx.doi.org/10.1016/j.biocon.2008.07.014

Resasco, J., N. M. Haddad, J. L. Orrock, D. Shoemaker, L. A. Brudvig, E. I. Damschen, J. J. Tewksbury, and D. J. Levey. 2014. Landscape corridors can increase invasion by an exotic species and reduce diversity of native species. Ecology 95(8):2033-2039. http://dx.doi.org/10.1890/14-0169.1

Root, T. L., D. P. MacMynowski, M. D. Mastrandrea, and S. H. Schneider. 2005. Human-modified temperatures induce species changes: joint attribution. Proceedings of the National Academy of Sciences 102(21):7465-7469. http://dx.doi.org/10.1073/ pnas.0502286102

Seastedt, T. R., R. J. Hobbs, and K. N. Suding. 2008. Management of novel ecosystems: Are novel approaches required? Frontiers in Ecology and the Environment 6(10):547-553. http://dx.doi. org/10.1890/070046

SINAC [Sistema Nacional de Áreas de Conservación]. 2009. Plan estratégico del Programa Nacional de Corredores Biológicos de Costa Rica para el quinquenio 2009-2014. SINAC, San José, Costa Rica. [online] URL: http://www.sinac.go.cr/corredoresbiologicos/ documentacion/plan estrategico pncb.pdf

Sinclair, S. J., M. D. White, and G. R. Newell. 2010. How useful are species distribution models for managing biodiversity under future climates? Ecology and Society 15(1): 8. [online] URL: http:// www.ecologyandsociety.org/vol15/iss1/art8/.

Stork, N. E., J. A. Coddington, R. K. Cowell, R. L. Chazdon, C. W. Dick, C. A. Peres, S. Sloan, and K. Willis. 2009. Vulnerability and resilience of tropical forest species to land-use change. Conservation Biology 23(6):1438-1447. http://dx.doi.org/10.1111/ j.1523-1739.2009.01335.x 
Stringer, L. C., A. J. Dougill, E. Fraser, K. Hubacek, C. Prell, and M. S. Reed. 2006. Unpacking "participation" in the adaptive management of social-ecological systems: a critical review. Ecology and Society 11(2): 39. [online] URL: http://www. ecologyandsociety.org/vol11/iss2/art39/.

Swallow, B. M., M. F. Kallesoe, U. A. Iftikhar, M. van Noordwijk, C. Bracer, S. J. Scherr, K. V. Raju, S. V. Poats, A. Kumar Duraiappah, B. O. Ochieng, H. Mallee, and R. Rumley. 2009. Compensation and rewards for environmental services in the developing world: framing pan-tropical analysis and comparison. Ecology and Society 14(2): 26. [online] URL: http://www. ecologyandsociety.org/vol14/iss2/art26/.

Tompkins, E. L., and W. N. Adger. 2004. Does adaptive management of natural resources enhance resilience to climate change? Ecology and Society 9(2): 10. [online] URL: http://www. ecologyandsociety.org/vol9/iss2/art10.

Townsend, P. A. 2011. Conservation and restoration for a changing climate in Monteverde, Costa Rica. Dissertation. University of Washington, Seattle, Washington, USA.

Walker, B., C. S. Holling, S. R. Carpenter, and A. Kinzig. 2004. Resilience, adaptability and transformability in social-ecological systems. Ecology and Society 9(2): 5. [online] URL: http://www. ecologyandsociety.org/vol9/iss2/art5.

Wessels, K. J., S. Freitag, and A. S. van Jaarseld. 1999. The use of land facets as biodiversity surrogates during reserve selection at a local scale. Biological Conservation 89(1):21-38. http://dx.doi. org/10.1016/S0006-3207(98)00133-5

Williams, J. W., and S. T. Jackson. 2007. Novel climates, no-analog communities, and ecological surprises. Frontiers in Ecology and the Environment 5:475-482. http://dx.doi.org/10.1890/070037

Wunder, S. 2007. The efficiency of payments for environmental services in tropical conservation. Conservation Biology 21 (1):48-58. http://dx.doi.org/10.1111/j.1523-1739.2006.00559.x

Zuchowski, W. 2007. Tropical plants of Costa Rica: a guide to native and exotic flora. Cornell University Press, Ithaca, New York, USA. 